\title{
Andrea Bellot*
}

\section{REVISITING THE PAST, NARRATING WAR MEMORIES: RETELLING THE FALKLANDS WAR IN A SOLDIER'S SONG}

\begin{abstract}
Private Ken Lukowiak was a member of the Second Battalion Parachute Regiment (2 PARA) of the British Army deployed to the Falkland Islands for the 1982 British-Argentine conflict. The veteran's creative drive motivated him into writing down his memories, and writing helped him overcome his war traumas. This paper seeks to explore Lukowiak's memoir as a work offering an alternative retelling of the Falklands War, based on a deep emotional framework, in contrast to the narrative of heroism favoured by mass media. His personal account emphasizes the psychological distress and detachment of a soldier in opposition to the supposedly exemplary and outstanding behaviour of troops as often portrayed in mainstream journalism during and after the armed conflict.
\end{abstract}

Keywords: A Soldier's Song (K. Lukowiak, 1993); Falklands War military memoir; war memories revisited; war recollections; rewriting war trauma.

\section{Revisiting War Memories in Writing}

Memory and identity formation are closely linked, since "memory is intimately connected to the way we constitute our selves" (Coker and Yeung 293). By remembering and revisiting our past, we construct our present and future self-identity, as well as group-identity. As King suggests, "memory can ... articulate the complex relationship between past, present and future in human consciousness" (11). Past wars are frequently remembered in commemorative practices, in journalism, historical works, war memorials and monuments, but also in artistic representations of war-sculpture, painting, music, literature, and drama. War remembrance and commemoration serve to recall past experiences of suffering, but at the same time, of resistance and heroism. That is why

\footnotetext{
${ }^{*}$ Universitat Rovira i Virgili (URV), Tarragona; Spain.
} 
mnemonic battles, such as the battle of Goose Green in the Malvinas/Falklands War, occupy a central position in the narratives of war recollection. In war accounts, authenticity emerges as an imperative for any narrative. The living witness acquires authority and credibility as a primary source in the re-telling of the past (Maltby), being that an ex-soldier or a journalist reporting from the battlefield. War veterans writing down their own war recollections and experiences on paper own a greater sense of authenticity. Yet, even if historians and journalists rely on historical facts, memoirs and autobiographies rely more on memory and feelings to recover the truth of past experiences. The validity and veracity of memory itself can also be questioned.

Even when memory plays a crucial role in the retelling and reconstruction of the past, it is widely agreed that the representation of traumatic experiences is beyond language: language proves insufficient to express the horror of hatred, violence, terror, panic. McLoughlin argues that "the representation of war is inherently anxiogenic" because "even if it resists representation, conflict demands it" (6). Memory and the fact of writing war recollections are central elements to overcome war-related traumas since the representational anxieties will function to vocalise the veterans' struggle with the past as a way to challenge the unbridgeable gap between language and the reality of war. Alongside this eagerness to keep certain experiences fresh and alive in the soldiers' minds, some memories are inevitably lost, or else they are too painful to bring back to the surface.

War is a transformative and life-changing experience, and, in Hynes's words: "no man goes through a war without being changed by it, and in fundamental ways" (3). Such a traumatic experience produces deep and longlasting effects on the combatants' physical as well as mental well-being. As Raman puts it, "there is no switch in the human mind which can periodically convert a kind soldier, who rescues victims from natural disasters, and then back again [to the battlefield], without affecting his mental state" (para. 12). The profound changes a combatant undergoes when returning from the battlefield are not always visible. Some veterans struggle to find the courage to share their war traumas. Many combatants endure painful emotions, such as guilt and shame, which prevent them from showing their true feelings in a society that rewards strength and bravery but stigmatises the weak and those seeking help (Farnsworth et al.; Nazarov et al.). Winter reflects on the silence of war veterans and their incapacity or unwillingness to narrate their war memories: 
Many of those who fought never spoke about what they knew. There were many reasons they placed their memories of war beyond words. Some felt that civilians could not comprehend and did not want to hear what they had to say. Some wanted to leave their nightmares in the dark, where they belonged, and to go on living ordinary lives. Others went further and concluded that the horror of war was beyond speech, beyond images, beyond monuments. What war did was to place itself beyond utterance (172).

Writing is one way of dealing with the ordeal of war recollections. For this reason, war memoirs have long been explored as works of traumatic recovery and personal "scriptotherapy," a term coined by Henke to refer to the therapeutic treatment in which writing is used as an instrument in the process of healing. The re-enactment of traumatic memories on paper provides a valuable discursive space for overcoming psychological wounds. Therefore, writing, especially autobiographical writing can be a form of generating personal catharsis.

In this sense, personal narratives can contain numerous disturbing elements that reflect the authors' traumas. According to Harari (Martial Illusions), modern war memoirs aim to reconnect authors to their lives after they had been disrupted by war. The main focus of war memoirs written by soldiers is, according to Jenkings and Woodward, "on the individual's experience rather than on broader reflection on the rationale for a conflict and its progress through time" (339). A model of narrative analysis has been put forward to address how the form and content of the stories serve the purpose of reconciliation, that is, achieving "harmony between past, present and future" (Hunt 117). The existence of a fragmented, disrupted life narrative and threatening flashbacks form a fundamental part of the clinical definition of Post-Traumatic Stress Disorder (PTSD). Reconstruction, harmonisation, and the creation of coherent memories are considered by psychologists to be essential for recovery.

These days, narrating war recollections from the battlefield is a personal experience that tends to focus on the individual, the inner reactions, and subjective experiences of the combatants, as Harari observes (Military Memoirs), rather than on historical facts or military details. Modern-day memoirs, then, have shifted from the traditional war stories of military officers, historians, and politicians to those of the people who actually fought and suffered on the 
battlefield. Personal narratives like these, Begley argues, "deliberately undermine sanitized abstractions of the war by reinscribing the terrifying immediacy and absurd singularity of combat experience ... into disordered narratives of combat fatigue and brute survival" (235). Kleinreesink groups war memoirs according to their themes into three broad categories: pure "action" memoirs, "growth" memoirs, and "disenchantment" memoirs. Negative narratives regarding war recollections structured around personal degeneration, shattered ideals, and disillusionment, are commonly authored by traumatised veterans. As Shay reveals, such damaging memories show the consequences of "betrayal of what is right" on the part of the soldier (11). Positive outcomes, in terms of personal maturation or lessons learnt, carry important weight in the published accounts of the professional soldiers of our times. Even personal disappointment is often channelled into positive debate and action, rather than a loss of control (Kleinreesink).

Private Ken Lukowiak's case provides a good example of the use of writing as a form of therapy. After the war, he underwent a long period of depression and Post-Traumatic Stress Disorder (PTSD), yet the veteran's creative drive motivated him to write down his memories, to help him overcome his war traumas. He needed an organised, written account of his daily experiences during that time to make sense of the war, to understand what he had been through, to heal, and move forward. A Soldier's Song is one of the three best known personal accounts of the Falklands War written by combatants, together with Vincent Bramley's Excursion to Hell (1992), Forward into Hell (2006) and John and Robert Lawrence's When the Fighting is Over: Tumbledown (1988). Due to its originality and rich narrative composition, this memoir has been praised for its literary merits that go beyond those of simple, crude veterans' accounts. McGuirk regards the book as "by far the most literary of combatants' memoirs" (101) and worthy of literary analysis along with novels, plays, and poetry. In fact, the book has been adapted for the stage. In 1998, Guy Masterson adapted, directed, and solo-performed the theatrical piece, and, in 2012, the show was revived but this time with Lukowiak on stage, performing his own memories.

In the foreword to the 1999 edition, Lukowiak explains his creative process in writing the book. For the veteran, writing was more of an impulse and not something that he had considered doing previously with a specific purpose in mind; he became a writer by accident: "one day, during a period of total despair, I picked up a pen and began to write down my memories of Goose Green" (xiv). 
Writing was not then conceived as part of a medical procedure Lukowiak had been advised to follow but was a way of expressing himself and of sharing his inner emotions, his artistic drive, and personal creation. Moreover, it turned out to be a salvation from the unpleasant, chaotic, and painful life he was leading: "and that despair, which I now look back on as emotionally the blackest period of my life ... I was a fine description of broke in every sense of the word" (Lukowiak xiv-xv). Writing became his only way of making sense of the world and of understanding the war, as well as a refuge, a source of happiness, and soon he became addicted to it and needed to do it to remain sane; it was like a drug:

I couldn't stop writing. The only description I've been able to come up with to explain the feeling, the absolute click of the fingers change in me, is that it was like a drug had been injected into my veins. I wrote and wrote and wrote. Couldn't stop. If I was sleeping, I was writing ... As my war poured out, I relived memories that had torn me apart. One time I even remembered the fear ... Once I finished putting down a particular memory, I always felt some sense of achievement, pride in myself (Lukowiak xviixviii).

\section{Combat Recollections in A Soldier's Song}

A Soldier's Song follows a loose chronological order, spiked with flashforwards and flashbacks, of a series of short chapters with titles evocative of ideas, associations, or resemblances. The subtitles are followed by a broad geographical position. Within each section, facts and military details intertwine with personal observations, dreams, and reflections. The author marks the beginning of these digressions from the main events with the phrases "I time flashed..." or "I time flashed again..." (italics in the original), which help the reader distinguish one thing from the other. Language is central both for expressing and healing trauma, and communication is a key factor in PTSD treatment. In this sense, the overall organisation of the book seems to recall the therapeutical work on dreams carried out by therapists with traumatised veterans. The book is, on the one hand, strongly emotive since it includes deep personal feelings and thoughts, and on the other, full of military-style anecdotic or trivial facts, which give readers a glimpse of military life. The writing style is sometimes harsh and direct, while at times it shows a remarkable literary and aesthetic density, but 
there are clear transitions from one style to the other via divisions of thematic chapters though often also intertwined within the same section. The use of dark irony is another distinctive mark of the text. The register is far from being the formal speech of military history texts; as a personal account, it intends to reflect the direct slang of the soldiers. The language of the actual actions is harsh, direct, and mostly colloquial. The use of military slang shows the key role that language plays in constructing and maintaining the cohesion and identity of the group. The use of martial jargon is another element of deliberate military training, aimed to separate the soldier from their former life and language and make them focus on this new universe (Parr). The 'group' represents a major psychological reference for any combatant, and even after the war, the group often remains the only admittable community with which the veteran feels free to share their memories. Language is therefore specific to the group but also critical to the process of re-elaboration of traumatic memories, and to the ability of veterans to express them outside their own restricted group of fellow veterans.

The comparatively important role of the subjective provides a starting point for multiple re-telling and reinterpretation of past memories. This kind of account, no doubt, served the author for the purpose of healing. Shocking and terrible facts were presented and immediately after, the story jumps to unreal scenarios or out of place childhood memories. In this sense, this very personal character of the story looks almost like a purpose-fit account, specific for a single person. Scarce hard-factual information from the field, or about a wider scope of events, is included, thus the focus of the text tends to lean to the anecdotal. Warlike memories are, then, mixed and conditioned by flashbacks and oneiric paragraphs, where visions, evocations, and civilian life memories make the reader think about the degree of conscious presence of the terrorised soldier on the battleground. Several flashbacks are triggered by terror episodes, for example, a section about the threat of an incoming air attack is followed by a dream of his former wife and this unexpectedly, begins to mix and interfere with his real actions:

We knew the Argentine jets would come soon ... I was in a panic. I had just married and Carol would be arriving soon. I needed to dig a bigger trench ... Looking down on me were two soldiers ... One of them asked where the mattress for my wife was (22). 
Regarding personal feeling and emotions that the combatant remembers from the war, fear, and even panic, is a frequent and recurrent element in the narration of events, present from beginning to end-from the moment of the disembarkation until the Argentinean surrender: "I was once again gripped by panic" (122). A key passage in the book in terms of despair is when the author realizes that nothing valuable was learnt, that no maturation process occurred, that his only ambition was to get out alive, and that "we behaved in the way that we had been conditioned to behave" (88). The frustration is eventually replaced by a necessary indifference and disillusionment, well reflected during the killing of a badly wounded enemy: "I felt nothing, we moved on" (36). It is arguable up to what point the complex mixture of sensations that a soldier experiences on the frontline, "moods like fear, anticipation, helplessness, praying and cursing, adventure and longing succeed each other like lightning" (Gray 13) could actually be remembered and replicated on paper.

As previously mentioned, in Lukowiak's memoirs, sentiments and emotions are often presented in the form of "time-flashes" and post-event reflections, sometimes developed during the actual writing, years later, but we can assume undoubtedly that they came into being at that time. As Shay points out, the blocking-out of further thinking is a survival strategy, as it is also the destruction of time. In combat, past, future and one's own values collapse, in a contraction of the temporal and moral horizon: "only getting through now has any existence" (italics in the original) (Shay 176). Lukowiak's apparent lack of feelings relates to the above-mentioned contraction of time, values, and references, a phenomenon experienced by soldiers on the battlefield during the most dramatic moments ${ }^{1}$. Lukowiak's work is a necessary contrasting view in front of other personal narratives of 'personal growth', redemption, 'closing the circle' more endorsed by mainstream media (Maltby). In fact, media, probably the main source of information about the conflict for the population, carefully avoided, during the conflict and afterwards - war anniversaries, commemorative events - remembering the war in anything resembling what Lukowiak recalls and reflects in his memories. In the media, the description of the struggle has been often reduced to a mere expression of 'toughness'; war was just tough, but

\footnotetext{
${ }^{1}$ There are several examples in which the writer seems not to experience deep feelings in the face of tragedy: "Death, polystyrene and me" (36); "Who's dead? He's dead" (50) (about Colonel Jones's death); "Cigarette smokers in black plastic bags" (99); and "Headless, legless, lifeless smokers" (147) (vision of a dead Argentine), to mention but a few.
} 
the audience is reassured that it was worth it, though.

The veteran's disillusionment transcends his personal experience on the battlefield to encompass larger cultural and psychological contexts that have been associated with the Falklands War, such as the patriotic militarism and the public mythologisation of this 'small' and unpredicted war. The Falklands War was, when compared to others, a brief conflict, but it was also a war that should not have happened, a kind of miscalculation caused by failure of politics, diplomacy, and military deterrence (Beattie) ${ }^{2}$. Although it took place in a remote location, largely unknown by many Britons until that day, the Falklands War soon became strongly supported and popular in Britain, after a brief period of disorientation (Robinson). Crowds gathered at the ports to say farewell to the expeditionary forces and warmly welcomed their heroes who returned home. For many, the war represented the opportunity to show the world that Britain was still a major world power and correct a perceived trend of decline that had led to believe that the role of Britain as a global military power was over (Parr).

It is widely acknowledged that the Falklands victory boosted Prime Minister Margaret Thatcher's popularity and helped her win the general election of 1983: from being considered by many as the most unpopular of British prime ministers, she managed to become one of the most popular. She was re-elected in 1983, successfully channelling the strong public support from this reawakened nationalist mood into the polls ${ }^{3}$. As Pearce and Stewart argue: "The dark days of the Falklands War were over and the country could rejoice in its recent victory and feel that Britain's prestige had risen under the stern and unyielding leadership of Mrs. Thatcher" (525). Similarly, Foster (Fighting Fictions) argues that Thatcherism was embodied in a narrative framework of an epic account of a heroic vision of the nation and a return to Victorian values. Foster (Fighting

22 Excellent accounts of the military, political, and mediatic aspects of the conflict have been produced, and they often highlight that the British victory came as a consequence of the superior quality of its troops but that it was also achieved by a narrow margin (See, for example, Hastings and Jenkins; Bicheno). It has been reported that success was due largely to section commander and private initiative and determination (Parr). Perhaps if Argentina had attacked a few months later, when Britain's already decided on defence budget cuts had been made effective and had depleted its forces' projection capability, it would not have had the capacity to deploy troops to such a remote location (Jenkins).

3 The Conservatives were 188 seats ahead of Labour and had an overall majority of 144 constituencies. The Labour Party recorded its worst performance since 1918, obtaining only $27.6 \%$ of the popular vote (Pearce and Stewart 526). 
University of Bucharest Review $\propto$ Vol. XI/2021, no. 1 (new series)

Re-writing, Re-imagining the Past (III)

Fictions) terms these dominant narratives about the Falklands War as 'fictions', or 'myths' that were appropriated by the British government and the media to instil the belief that the campaign to retake the islands has been a moral and political crusade and that the war was fought in the name of the public good. When the Prime Minister came into power in 1979, she was determined to halt Britain's decline and restore the nation's pride. Thatcher believed that the role of the Task Force in the defeat of Argentina was a direct consequence of the application of Victorian values and national greatness: "she identified the primary cause of Britain's victory in the South Atlantic with the same rigid hierarchies of rank, class, race and gender that has provided the functional and ideological focus of the empire" (Foster, To Serve 236). In a similar vein, Monaghan observes how these 'official myths' were put forward by Thatcherism to promote a national rebirth in British identity, and, to that end, the Falkland Islanders were depicted as "British in stock and tradition", an "island race" that deserves to be protected (25-6). The nation has found itself again in battle and its strength has been reborn in the 'spirit' of the South Atlantic. According to Barnett, "the example of the task force was its professional leadership and its clear hierarchy of rank" (63), and this good example set by the Task Force and by all those who contributed to the battle should be followed - the 'commanders in the field' should be imitated at home.

\section{Conclusions}

Ken Lukowiak's A Soldier's Song provides a poignant reminder of the horrors of war. Only feelings and recollections from someone who has been on the battlefield are indisputable because they belong to the individual and their own suffering, regardless of how subjective or biased these emotions and memories can be. This is a quality edge not shared by other equally valuable living witnesses, like the embedded war reporters. The readers discover that war has been for Lukowiak, for a long time, a 'job to be done', for which he was 'conditioned to behave' through training that creates automatic killing routines, erases questioning, and focuses on the "hows" and prohibits the "whys." But eventually, the human side always reappears, either in the form of compassion, or madness or by veterans ending up in a berserk state. The overall style, tone, and themes in Lukowiak's work suggest disenchantment, with scarce room for learning or personal maturation. However, writing his war recollections has been, for Lukowiak, a vital way to cope with the traumatic recollections of the 
war. After a long period of depression and instability, this Falklands War veteran seems to have been able to redirect his life course through writing, journalism, and collaborative experiences in war-affected countries, as he explains in the foreword of his book. War memoirs play an important as a counterbalance narrative of war trauma in a world dominated by hegemonic mass media, for whom the collective dimension of the war is the primary concern. In contrast, personal emotions, reflections, and criticism can be formed and delivered to the readership by means that can form a counternarrative, even if less constrained by requirements of historical or factual accuracy.

\section{Works Cited}

Barnett, Anthony. Iron Britannia. London: Allison and Busby Ltd, 1982. Print.

Beattie, Troy. Conventional Deterrence and the Falkland Islands Conflict, Doctoral dissertation. Monterey: Naval Postgraduate School, 2010. Print.

Begley, Jon. "The Literature of the Falklands/Malvinas War." The Edinburgh Companion to Twentieth-century British and American War Literature. Ed. Adam Piette and Mark Rawlinson. Edinburgh: Edinburgh University Press, 2012: 231-40. Print.

Coker, Thomas F., and Heather H. Yeung. "Remembering Responsibly." Memory in the Twenty-First Century: New Critical Perspectives from the Arts, Humanities, and Sciences Ed. Sebastian Groes. Hampshire and New York: Palgrave MacMillan, 2016: 292-7. Print.

Farnsworth, J. K., K. D. Drescher, J. A. Nieuwsma, R. B. Walser, and J. M. Currier. "The role of moral emotions in military trauma: Implications for the study and treatment of moral injury." Review of General Psychology 18 (2014): 249262. Print.

Foster, Kevin. "To serve and protect: Textualizing the Falklands conflict." Cultural Studies 11:2 (1997): 235-252. Print.

---. Fighting Fictions: War, Narrative and National Identity. London: Pluto Press, 1999. Print.

Gray, Glenn J. The Warriors. Reflections on Men in Battle. Lincoln and London: University of Nebraska Press, 1959. Print.

Harari, Yuval. "Martial Illusions. War and Disillusionment in Twentieth-Century and Renaissance Military Memoirs." Journal of Military History 69,1 (2005): 43-72. Print. 
University of Bucharest Review $\propto$ Vol. XI/2021, no. 1 (new series)

Re-writing, Re-imagining the Past (III)

---. "Military Memoirs: A Historical Overview of the Genre from the Middle Ages to the Late Modern Era." War in History 14,3 (2007): 289-309. Print.

Henke, Suzette A. Shattered Subjects: Trauma and Testimony in Women's Life Writing. London: Macmillan Press Ltd., 1998. Print.

Hunt, Nigel. Memory, War and Trauma. Cambridge: Cambridge University Press, 2010. Print.

Hynes, Samuel. The Soldier's Tale: Bearing Witness to Modern War. London: Penguin Books, 1998. Print.

Jenkins, Simon. "The Luck of the War." The Sunday Times. Culture. 9 July 2006: 35-6. Print.

Jenkings, K. Neil, and Rachel Woodward. "Practices of authorial collaboration: The collaborative production of the contemporary military memoir." Cultural Studies, Critical Methodologies 14, 4 (2014): 338-350. Print.

King, Nicola. Memory, Narrative, Identity. Remembering the Self. Edinburgh: Edinburgh University Press, 2000. Print.

Kleinreesink, Esmeralda. On Military Memoirs: Soldier-authors, Publishers, Plots and Motives. Doctoral dissertation. Rotterdam: Erasmus University, 2014. Print.

Lukowiak, Ken. A Soldier's Song. $2^{\text {nd }}$ ed. London: Phoenix, Orion Books Ltd, 1999. Print.

Maltby, Sarah. Remembering the Falklands War. Media, Memory and Identity. London: Palgrave Macmillan, 2016. Print.

McGuirk, Bernard. Falklands-Malvinas. An Unfinished Business. Seattle: New Ventures Editions, 2007. Print.

McLoughlin, Kate. Authoring War: The Literary Representation of War from the Iliad to Iraq. Cambridge: CUP, 2011. Print.

Monaghan, David. The Falklands War: Myth and Countermyth. London: Macmillan, 1998. Print.

Nazarov, A., R. Jetty, H. McNeely, M. Kiang, R. Lanjus, and M. C. McKinnon. "Role of morality in the experience of guilt and shame within the armed forces." Acta Psychiatrica Scandinavica 132 (2015): 4-19. Print.

Parr, Helen. Our Boys. The story of a Paratrooper. Milton Keynes: Penguin Random House, 2019. Print.

Pearce, Malcolm, and Geoffrey Stewart. British Political History. London: Routledge, 1992. Print.

Raman, Raghu. "The Psychological Toll of Being a Soldier." The Wire. 13 September 2019. Print. 
Robinson, Lucy. "Soldiers Stories of The Falklands War: Recomposing Trauma in Memoir." Contemporary British History 25: 4 (2011): 569-89. Print.

Shay, Jonathan. Achilles in Vietnam: Combat Trauma and the Undoing of Character. New York: Scribner, 1994. Print.

Winter, Jay. Remembering War. New Haven and London: Yale University Press, 2006. Print. 